\title{
Feyerabend on Art and Science
}

\author{
Chiara Ambrosio \\ Department of Science and Technology Studies
}

UCL

c.ambrosio@ucl.ac.uk

\section{Introduction}

Paul Feyerabend's philosophy is replete with artistic metaphors. From theatre to literature, music and painting, the arts were used by Feyerabend not merely as decorative examples to showcase a form of contrived erudition, but as a coherent conceptual framework to articulate key methodological and epistemological questions. With a few isolated exceptions (Couvalis, 1987; Brown, 2009; Kidd, unpublished manuscript), philosophers of science have paid little attention to this intriguing and extremely fruitful aspect of Feyerabend's work.

In this chapter I bring together several strands of Feyerabend's history and philosophy of art and place them in dialogue with the pluralist outlook that characterises his philosophy of science. Scholars have recently re-evaluated Feyerabend's pluralism as a positive thesis running as a coherent thread throughout the various developments of his thought (Preston 1997; Shaw 2017; and to a certain extent Oberheim 2006 - insofar as he sees pluralism as Feyerabend's response to and attack on conceptual conservativism). Art was part and parcel of this philosophical and pluralist strategy. It is in the background of Feyerabend's early critique of empiricist accounts of observation and experience (Feyerabend 1962, 1965) ; it is the springboard to launch into a celebration of styles, to demonstrate the dynamic character of early philosophies of nature and their functioning as coherent worldviews (Feyerabend 2016); it is the foil against which arguments about incommensurability and critiques of progress could be tried and tested (Feyerabend 1975; Feyerabend 1984) ; it affords a concrete opportunity for blurring the lines between theory and practice (Feyerabend 1994; Feyerabend 1996), in a way that resonates with analogous debates in the historiographies of science and art alike (Hacking 1983; Shapin 1989; Smith 2004; Field 2004, 2016).

Feyerabend's views on art and choices of examples from artistic practice are as varied as the arguments they are intended to support. Here I will concentrate on his views on representation - a particular line of investigation which seems to emerge as a recurrent motif especially in his discussions of the visual arts in relation to science. I will start from his late writings, where issues of representation are central to his return to the "problem of reality" (Feyerabend 1999; see also Kidd 2010). ${ }^{1}$ This is perhaps the aspect of Feyerabend's posthumously published book, Conquest of Abundance (1999), which has been connected more explicitly with his writings on art (Oberheim 2006, p. 23; Brown 2009, pp. 216-7). But I also want to show that the discussion of art - particularly of projective techniques in the invention of perspective - in Conquest of Abundance is the culminating point of a much longer journey, which saw Feyerabend wrestling with the "naïvely imitative philosophies" lurking in the background of empiricist as well

\footnotetext{
${ }^{1}$ I follow the periodisation of Feyerabend's philosophy proposed by Brown and Kidd (2016, p. 3).
} 
To appear in Karim Bschir and Jamie Shaw (eds), Interpreting Feyerabend: Critical Essays Cambridge University Press

Please cite from the published version

as realist positions in philosophy of science. A turning point in this journey is the essay Science as Art $(1984),{ }^{2}$ which introduces examples and arguments that Feyerabend would revisit over a decade later, in Conquest of Abundance. Comparing these two texts, I will single out two interconnected lines of inquiry that characterise Feyerabend's approach to representation. One is the pervasiveness of the issue of artistic styles, which Feyerabend exploits as a springboard to question "naïvely imitative" views in science. In this, I argue, he adopts a distinctive art historical methodology, which can be traced back to the anti-mimetic legacy of the Vienna School of Art History. ${ }^{3}$ The other is the question of imitation as a conceptual category in its own right, and its relation to representation. Here Feyerabend's ideas shift and align with the various phases of his philosophy. Science as Art, written in the mid-1980s, draws on the analogy between styles in art and science to expose the flaws inherent in a linear notion of scientific progress. In this context, "naïvely imitative philosophies" form the core of Feyerabend's attack against a narrow conception of progress construed as increasing fidelity to nature. Conquest of Abundance, on the other hand, rescues a role for imitation as a dynamic and performative category, which can be productively carried over from the arts to science, and which is in tune with the exploration of "the richness of Being" distinctive of the late Feyerabend. If there is a space for imitation in science (and for the late Feyerabend this is indeed the case, though he never reduced representing to imitating), I argue, it is precisely in this performative sense, as an invitation to explore how reality is reconfigured in the process of imitating it.

\section{2. "The Ugly Madonna of Siena"}

Chapter four of Feyerabend's Conquest of Abundance opens with an intriguing discussion of the "ugly Madonna of Siena" (Feyerabend 1999, p. 89), the so-called Madonna dagli Occhi Grossi (fig. 1). The painting, produced in the second half of the XIII century and attributed to the Maestro di Tressa, occupied the high altar of the Duomo of Siena and was believed to have protected the Sienese army against the Florentine invaders at the battle of Montaperti in 1260 (Emmerson 2013, p. 180). The painting's name ("Madonna with big eyes") does not refer to the image itself, but to the eye-shaped ex-voto that surrounded it. As Feyerabend remarks, the image "worked miracles" (Feyerabend 1999, p. 89), especially in its ability to "mediate spiritual powers" (Feyerabend 1999, p. 92). Miraculous capacities notwithstanding, the Madonna dagli Occhi Grossi was soon found to be inadequate to the prominent place it occupied and replaced "by a suitable altarpiece of equal grandeur [as the altar]": Duccio di Buoninsegna's Maestá (1308-1311) (Emmerson 2013, p. 180).

Indeed, when contrasted with later images, the painting may be judged as hopelessly unrefined: perched on a backless throne, the Madonna lacks depth, roundness and perspective. Her arms are far too short and hold rather unnaturally the child in her lap. Her somewhat baffled expression appears more like an accident of the painting process than an intentional artistic choice. Feyerabend proceeds to compare the "ugly Madonna of Siena" with an image produced a quarter of a century later, Raphael's Madonna del Granduca (fig. 2). Drawing on an old trope in the history

\footnotetext{
${ }^{2}$ All my references to Science as Art are from the Italian edition, in bibliography as Feyerabend (1984).

${ }^{3}$ The Vienna School has a long and fascinating history, which has recently been revisited by art historians. See for instance Rampley (2013) and Elsner (2009). I will focus on two figures in particular, Alois Riegl and Sir Ernst H. Gombrich, who were direct influences on Feyerabend. Gombrich in particular might not be recognized as the most representative member of the Vienna School; but his recurrent criticism of Riegl and the acknowledged influence of Riegl on his The Sense of Order (1979) justify inscribing him at least in the School's critical legacy.
} 
To appear in Karim Bschir and Jamie Shaw (eds), Interpreting Feyerabend: Critical Essays Cambridge University Press Please cite from the published version

of art, he shows that the latter image could easily be judged as an "improvement" on the clumsy style of the former. This was the commonsense view of artistic representation that historians of art inherited from Giorgio Vasari's Lives of the Artists (c1550), where the trajectory from artworks like the Madonna dagli Occhi Grossi to the Madonna del Granduca is described as one of progress toward an increased fidelity to nature. Of Raphael, for example, in a passage cited by Feyerabend himself, Vasari states: "His figures expressed perfectly the character of those they represented, the modest or the bold being presented just as they are. The children in his pictures were depicted now with mischief in their eyes, now in playful attitudes. And his draperies are neither too simple nor too involved, but appear wholly realistic" (Vasari [1550] 1979, p. 252).

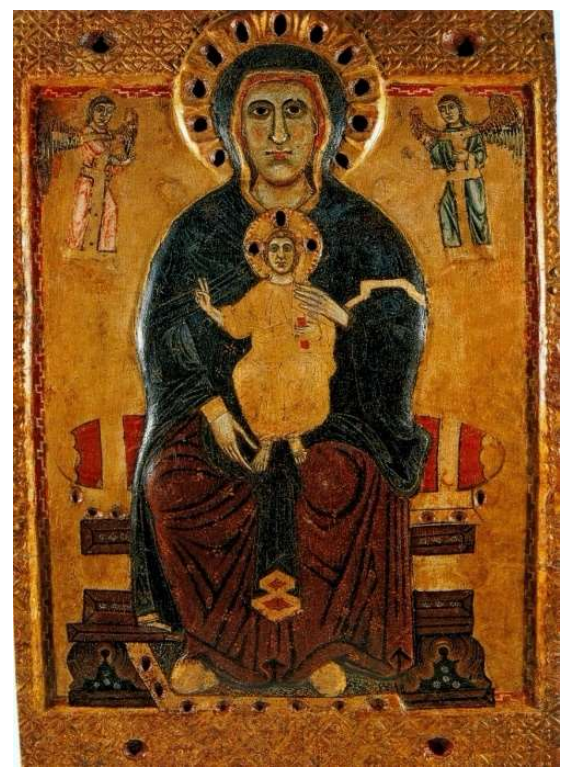

Figure 0-1: Maestro di Tressa, Madonna Dagli Occhi Grossi (c.1225). (C) Opera della Metropolitana ONLUS, Aut. N. 207/2020.

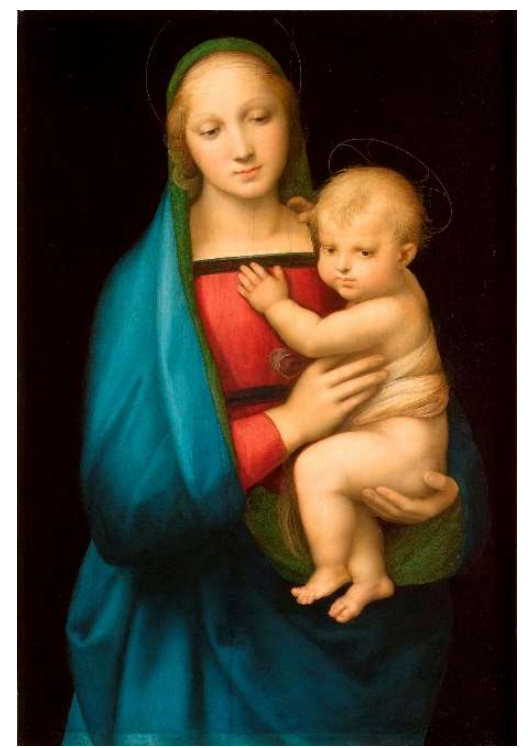

Figure 0-2: Raphael, Madonna del Granduca (c.1505). Palazzo Pitti, Florence. (C) Le Gallerie Degli Uffizi

The old trope of art progressing toward an increasing fidelity to nature is especially attractive to Feyerabend. Elaborating on Vasari, he reconstructs it as "the imitative view" of art: "Artists, says Vasari, try to represent real things and events. They do not immediately succeed; held back by ignorance and false traditions they produce stiff and crude images of lamentable proportions. But they gradually improve" (Feyerabend 1999, p. 90). This narrow view of representational success as increasing mimetic conformity to nature hardly constituted the canon in history of art in Feyerabend's time. ${ }^{4}$ But a critique of the legacy of Vasari's ideas, and more broadly of Renaissance art as the pinnacle of naturalistic representation, had been especially important in the establishment of history of art as a discipline in its

\footnotetext{
${ }^{4}$ The dawn of mimetic accounts of art and of a conception of representational success as increasing fidelity to nature is traditionally associated to the rise of the artistic avant-gardes. Arthur Danto $(1986 ; 1997)$, for instance, famously argued that the very notion of progress in the arts began to falter with the concomitant faltering of mimesis as a criterion for artistic representation from the second half of the nineteenth century onwards. Danto's reconstruction is by no means uncontentious; see for example Halliwell's (2002, pp. 369-70) criticism of the overly uniform view of mimesis implicitly built in his account.
} 
own right. ${ }^{5}$ What Feyerabend found particularly congenial in this strand of historical literature was the critique, conducted on empirical as well as theoretical grounds, of the marriage of progress and increased fidelity to nature. Vestiges of a similarly naïve imitative philosophy, he noted, still lurked in the background of contemporary celebrations of "the unprejudiced scientist who avoids speculation and "tells it like it is"” (Feyerabend 1999, pp. 9192). The very idea of artists "gradually improving" toward more realistic representations had a counterpart in both naïve empiricist and naïve realist accounts of science, which had formed the target of Feyerabend's philosophy all along. What made these positions naïve was an implicit, and narrow, form of representationalism, which Feyerabend aimed to expose through his comparison with art: representationalism about sense data as the immediate, uniform and stable contents of observation in the case of empiricism, and representationalism about the coherent, stable and unified structure of the world which successful scientific theories aim to mirror, in the case of scientific realism. ${ }^{6}$ Drawing on art for Feyerabend fulfilled a methodological aim with a clear epistemic import: to show, through visual as well as verbal arguments, the shortcomings of such narrow philosophical accounts of science.

It is important to note (and I will return to this point later) that the targets of Feyerabend's criticism here are neither representationalism nor imitation per se. In Conquest of Abundance he does in fact acknowledge that "there are artists who want to copy nature, and some succeed to a surprising degree" (Feyerabend 1999, p. 93). The question, as it is often the case in Feyerabend's writings, is how to reconcile imitation as one possible aim of representation with the inherent pluralism of artistic (and by implication, scientific) styles, even when they purport to copy faithfully from nature. The Madonna dagli Occhi Grossi, Feyerabend points out, "may have caught an element of reality that had disappeared by the time of Raphael - but this must be determined by research, not by metaphysical speculations about "the nature of reality" (Feyerabend 1999, pp. 93-94). Thus questioning a commonsense view of imitation in Conquest of Abundance aims to pave the way for a richer account of what is more broadly entailed in the process of representing, by showing the inherent complexity of even the most straightforward cases of artists directly "copying from nature". This is an issue that Feyerabend had started exploring much earlier in his writings, and to which I turn in the next section.

\section{Empiricism and Naïve Representationalism}

Conquest of Abundance is neither the first nor the sole text in which art appears as part of Feyerabend's argumentation. As early as 1965, in the essay "Problems of Empiricism", Feyerabend indulges in a long footnote, complete with images, to advance a historicised and contextual account of observation in response to the dominant empiricist view. Feyerabend's target there is the uniform and stable account of observation implicit in the empiricist theses that ideas derive from sensory experience (aided or unaided by instruments) and that the truth of statements

\footnotetext{
${ }^{5}$ As I will discuss below, the two sources most cited and used by Feyerabend, Riegl and Gombrich, were both strong opponents of the mimetic tradition and of the very idea of progress toward increasing naturalistic fidelity in the arts. See Riegl [1893] 1992, Riegl [1901] 1985 and Gombrich [1960] 2002. For an overview of the concept of style in relation to ideas of progress in the arts from Vasari to Feyerabend see Ginzburg (1998).

${ }^{6}$ Matt Brown (2016) has characterized this narrow and monistic version of realism as "scientific materialism", and opposed it to Feyerabend's (late) "abundant realism." I will return to Brown's position later on, as it offers a metaphysical counterpart to the reformulation of mimesis I pursue in this chapter. For a detailed account of Feyerabend's views on realism and their compatibility with his pluralism see also Hasok Chang's chapter in this volume.

${ }^{7}$ I am especially grateful to Matteo Collodel for alerting me to the existence of this rather precious footnote in Feyerabend's corpus.
} 
To appear in Karim Bschir and Jamie Shaw (eds), Interpreting Feyerabend: Critical Essays Cambridge University Press

Please cite from the published version

containing ideas thus formed can be straightforwardly verified by observation (Feyerabend 1965, p. 147). ${ }^{8}$ Lurking in the background of Feyerabend's criticism is a specific concern about the status of observational reports, and their treatment in empiricist accounts of science. As Feyerabend scholars have pointed out (Kuby 2015, Oberheim 2006), this concern is directly related to his critique of phenomenalist sense data epistemologies - the idea that sense data are the immediate objects of perception, and that statements about sense data enjoy a certainty that other kinds of statements lack. It is also a criticism of the ways in which some logical empiricists tried to avoid the identification with phenomenalist positions (e.g. Hempel 1952) by arguing that observational statements report directly observable and intersubjectively testable facts about physical objects. Both these variants of "radical empiricism", according to Feyerabend, revolved around "the common belief that experience contains a factual core that is independent of theories" (Feyerabend 1965, p. 151), which ultimately fixed the meaning of observation statements. "Problems of Empiricism" argues against the idea of a factual or "given" core and advances instead the claim that sensations and perceptions are at best indicators that function in a manner similar to physical instruments. This is also known as Feyerabend's version of the "pragmatic theory of observation": ${ }^{9}$ sensations and perceptions indicate that something exist, but they become descriptions of what exists only when used in a theory which provides their interpretation (Feyerabend 1962, pp. 36-37; Feyerabend 1965, p. 214ff).

The reference to art features in the very opening of "Problems of Empiricism", and supports Feyerabend's general point that, for a start, what counts as an "observational report" has been contentious across history. It also sets up the stage, through a psychological argument, for his criticism of a "given" core in experience, and particularly in the process of observation. It is here that a long footnote takes him into a detour on the dependence of perception upon belief, and from there to art:

That primitive people...live in an observational world very different from our own is shown by their art. It has been assumed for some time, no doubt under the influence of empiricism, that the 'primitive' character of these productions is due to lack of skill: these people live in the same perceptual world as we do, but they are unable to produce adequate copies of it (Feyerabend 1965, p. fn. 8 221).

The 1965 version of Feyerabend's argument runs along similar lines as the discussion of the Madonna dagli Occhi Grossi in Conquest of Abundance: naïvely imitative philosophies assume that there is a single, unified and stable perceptual world, and that it is the artist's (or scientist's) task to produce an adequate copy of it. But this representational realism, Feyerabend continues, is an "impossible doctrine":

\footnotetext{
${ }^{8}$ Feyerabend's critique of empiricism in the essay is admittedly much broader, and it is in line with the features that Brown and Kidd (2016) have identified as distinctive of his early philosophy: a defence of theoretical pluralism within science, as opposed to the monistic view implicitly built in "radical" forms of empiricism, a critique of verificationism and phenomenalist sense-data epistemologies, and a commitment to a variety of semantic or conjectural realism in interpreting scientific theories. For reasons of space I can only address some of these aspects of Feyerabend's early philosophy briefly, and I have chosen parts of his criticism of empiricism that are more explicitly in dialogue with his treatment of art in footnote 8 of "Problems of Empiricism."

${ }^{9}$ For detailed discussions of Feyerabend's pragmatic theory of observation see Kuby (2015) and especially Kuby (2018), which reconstructs in detail the relationship between Feyerabend and Carnap's respective versions of the theory.
} 
To appear in Karim Bschir and Jamie Shaw (eds), Interpreting Feyerabend: Critical Essays Cambridge University Press

Please cite from the published version

It assumes that there is only one correct way of translating occurrences in the three dimensional real world into situations portrayed in an altogether different medium. The world is as it is. The picture is not the world. What then, does the realist demand? He demands that the conventions to which he is accustomed (and which are only a meagre selection from a much wider domain of conventions) be adopted. That is, he makes himself the measure of the reality of things - the very opposite of what the realistic doctrine would allow. (Feyerabend 1965 , p. fn. 8221$)$

At this point Feyerabend's footnote explicitly turns to a classic study on the relation between perception and pictorial conventions in the arts: Sir Ernst Gombrich's Art and Illusion ([1960] 2002). Starting precisely from the legacy of Vasari's idea of progress in history of art, Gombrich argued that pictorial realism involved much more than just faithfully copying from an art-independent reality. Instead, convincing figurative representations are illusions, which involve the manipulation of inherited perceptual 'schemata' that designate reality by convention. It is the totality of these conventions at a particular time in history, according to Gombrich, that defines a pictorial style (Gombrich [1960] 2002, p. 246). The history of art, in his account, consisted in a sustained empirical and theoretical investigation precisely into the dynamics that underpin the rise and fall of pictorial styles, which he also saw as the basis of artistic change and of the inherent pluralism that characterised artistic representations across history.

Gombrich famously built his account of artistic illusion in dialogue with the psychology of perception, which he deemed essential to an investigation into the modes of production and interpretation of artworks. The image of the duck-rabbit made famous (at least among philosophers of science) ${ }^{10}$ by Thomas Kuhn, for instance, features in the introduction of Art and Illusion (first published two years earlier than The Structure of Scientific Revolutions), to show the impossibility of detangling perception from interpretation, and to highlight the crucial role of learning and expectation in making sense of the ambiguity that characterises what is before one's eyes - in real life just as in art making. "Painting is an activity", Gombrich claimed later on in the book, "and the artist will therefore tend to see what he paints rather than to paint what he sees" (Gombrich [1960] 2002, p. 73).

What perhaps attracted Feyerabend's attention toward Art and Illusion was the critique of the legacy of empiricism in art making, which Gombrich pursued with an eye to the works of his lifelong friend Karl Popper. ${ }^{11}$ " The inductivist ideal of pure observation has proved a mirage in science no less than in art", Gombrich pointed out, explicitly invoking Popper: "Every observation, as Karl Popper has stressed, is a result of a question we ask nature, and every question implies a tentative hypothesis" (Gombrich [1960] 2002, p. 271). This account of the conjectural nature of observation underpins Gombrich's appropriation of Popper's method of conjectures and refutations, and its application to the domain of art:

\footnotetext{
${ }^{10}$ On the history of the duck-rabbit before Kuhn, from its creator Joseph Jastrow, to Ludwig Wittgenstein see Viola (2012). On the relationship between science and art in the first manuscript of Kuhn's The Structure of Scientific Revolutions see Pinto de Oliveira (2017).

${ }^{11}$ Gombrich had been instrumental - among other things - in the publication of The Open Society and its Enemies (1946). For recent critical appraisals of the relationships between Popper and Gombrich see Hemingway (2009) and Schneider (2009). For recent reappraisals of Gombrich's place and influence on the field of history of art see Wood (2009) and Mount (2014).
} 
To appear in Karim Bschir and Jamie Shaw (eds), Interpreting Feyerabend: Critical Essays Cambridge University Press

Please cite from the published version

We look for something because our hypothesis makes us expect certain results. Let us see if they follow. If not, we must revise our hypothesis and try again to test it against observation as rigorously as we can; we do that by trying to disprove it, and the hypothesis that survives that winnowing process is the one we are entitled to hold, pro tempore.

This description of the way science works is eminently applicable to the story of visual discoveries in art. Our formula of schema and correction, in fact, illustrates this very procedure. You must have a starting point, a standard of comparison, in order to begin that process of making and matching and remaking which finally becomes embodied in the finished image. The artist cannot start from scratch but he can criticise his forerunners (Gombrich [1960] 2002, pp. 271-2).

Art "making" thus takes the form of a visual conjecture or hypothesis grounded in conventions. Conventions, in turn, serve as standards of comparison for any pictorial innovation introduced by the artist with a new representation. The new pictorial schemata are then "matched" against the world and corrected until the image satisfactorily resembles the portion of reality singled out by the artist. Figurative realism, for Gombrich, is the hard-won result of this process of trial and error, the successful matching between what artists make and what they expect to encounter in their field of perception, which is itself shaped by inherited conventions.

Although Gombrich remained somewhat ambiguous on this point, his account of representation in relation to the psychology of perception is neither constructivist nor entirely conventionalist. ${ }^{12}$ His main point in Art and Illusion is that there is some kind of "factual" content to our perceptions, but that content is inherently ambiguous and so our attempts at rendering it in a pictorial form are inevitably in the form of conjectures, formulated with the aid of a set of expectations. Ambiguity, in turn, for Gombrich "cannot be seen - it can only be inferred by trying different readings that fit the same configuration" (Gombrich [1960] 2002, p. 264). This ambiguity characterises the stage of "making" pictorial conjectures about the world as much as the stage of "matching" those conjectures to the ways in which the world is experienced from a particular perspective. "The world does not look like a picture but a picture can look like the world", Gombrich (1972, p. 138) explained in a later reflection on the key message of Art and Illusion. And yet that resemblance is an achievement of representation, not a relationship dictated by a unified and immutable reality.

In the long footnote to "Problems of Empiricism" Feyerabend singles out what is probably Gombrich's best known example to illustrate the conjectural nature of making, and the role of conventions as the starting point for the rendering of unfamiliar objects in painting. Albrecht Dürer's 1515 iconic rhinoceros woodcut (fig.3) is an instance of conjectural "making" that crystallised into a stylistic convention in its own right. Drawn from second hand evidence

\footnotetext{
${ }^{12}$ And yet he is often lumped in the conventionalist camp, alongside Nelson Goodman. This is because in Languages of Art Goodman himself coopted Gombrich into supporting his own conventionalist cause (Goodman 1976, 7). But Gombrich was adamant to distance his approach especially from the kind of nominalism underpinning Goodman's conventionalist approach: "He rather misunderstood my book. He interpreted it as completely 'conventionalist'", he explained in conversation with Didier Eribon (Gombrich 1993, p. 112). For further details on Gombrich's response to Goodman see Gombrich (1972), which incidentally contains also a discussion of Brunelleschi's perspectival rendering of the Baptisterium - an example taken up later by Feyerabend, as I show below.
} 
To appear in Karim Bschir and Jamie Shaw (eds), Interpreting Feyerabend: Critical Essays

Cambridge University Press

Please cite from the published version

(despite being presented in the caption as made "from life", which was a common trope at the time), and supplemented with representative conventions applied to other exotic animals, Dürer's rhinoceros is covered in a thick armour and presents a smaller spurious horn at the top of its neck. Gombrich ([1960]2002, p. 71) highlights that this image became the standard model for representations of the animal in natural history texts, even in the face of conflicting evidence from observational reports, and even after explorers and natural historians pointed out the difference between the (onehorned) Indian rhinoceros and the (two-horned) African rhinoceros (see fig. 4 and 5). ${ }^{13}$ This is a key point that Feyerabend illustrates with images in his footnote. Contrasting Dürer's original image with an eighteenth-century painting and a photograph of an African rhinoceros, Feyerabend adapts Gombrich's views to his main claim against the empiricist variant of naïve representationalism: "we find that conventions are not used only in the absence of the object, but exert their influence even when a direct account of the visible object is attempted" (Feyerabend 1965, p. fn. 8 221).

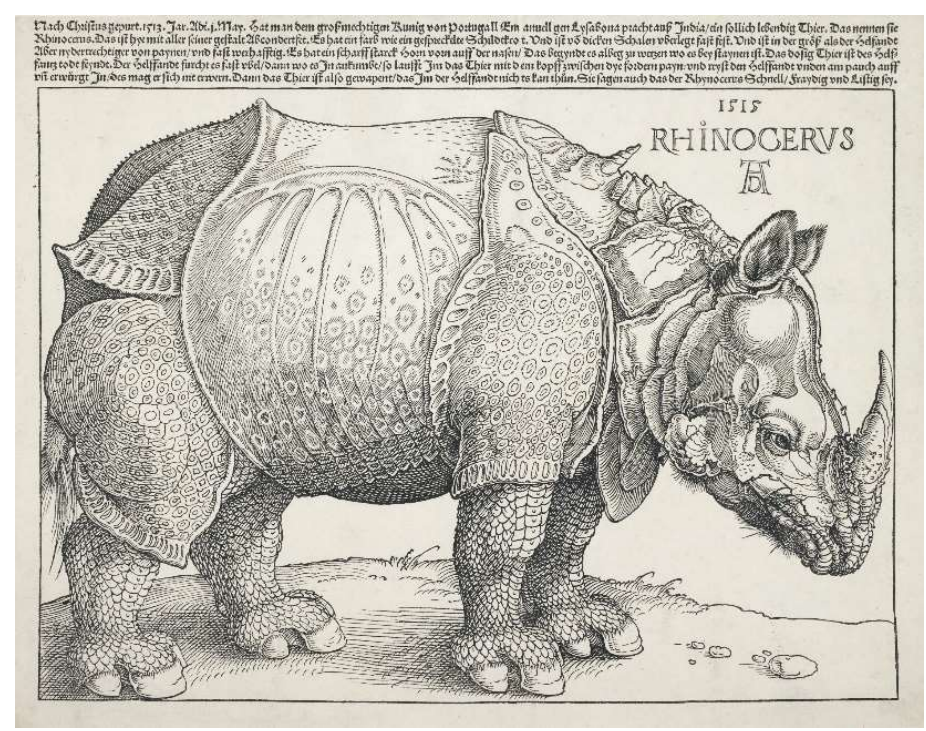

Figure 0-3: Albrecht Dürer, Rhinoceros. c1515. (C) The Trustees of the British Museum. All rights reserved.

\footnotetext{
${ }^{13}$ I have explored the relation between Dürer's iconic representation and the work of the eighteenth-century artist (and rhino-obsessed illustrator) Jan Wandelaar, whose representations are reproduced in fig. 4 and 5, in my Ambrosio (2015). Wandelaar was indeed one of the early illustrators who recognised the difference between African and Indian varieties, but he was also one of the first illustrators who attempted to subvert the established pictorial conventions by liberating the image of the rhino from its traditional armour. His 1727 illustrations of the rhinoceros, contained in a treatise on the flora and fauna of the Cape of Good Hope, would have greatly amused Gombrich and Feyerabend alike. Asked to produce an image in the manner of Dürer, Wandelaar made two different engravings: one labelled "the rhinoceros as it had been commonly depicted" (fig. 4), the other labelled "The rhinoceros according to this description" (fig. 5). See Ambrosio (2015, 123) and Rookmaaker (1976, p. 88). In a Feyerabendian spirit, I had originally placed Jan Wandelaar's images in this footnote. Alas - due to 'possible issues with repagination in certain e-formats' (personal communication), the twenty-first century digital press can no longer cope with images in footnotes, as it did in the case of Feyerabend's "Problems of Empiricism" in the 1960s. I imagine Feyerabend would be amused but not particularly surprised by this!
} 
To appear in Karim Bschir and Jamie Shaw (eds), Interpreting Feyerabend: Critical Essays Cambridge University Press Please cite from the published version

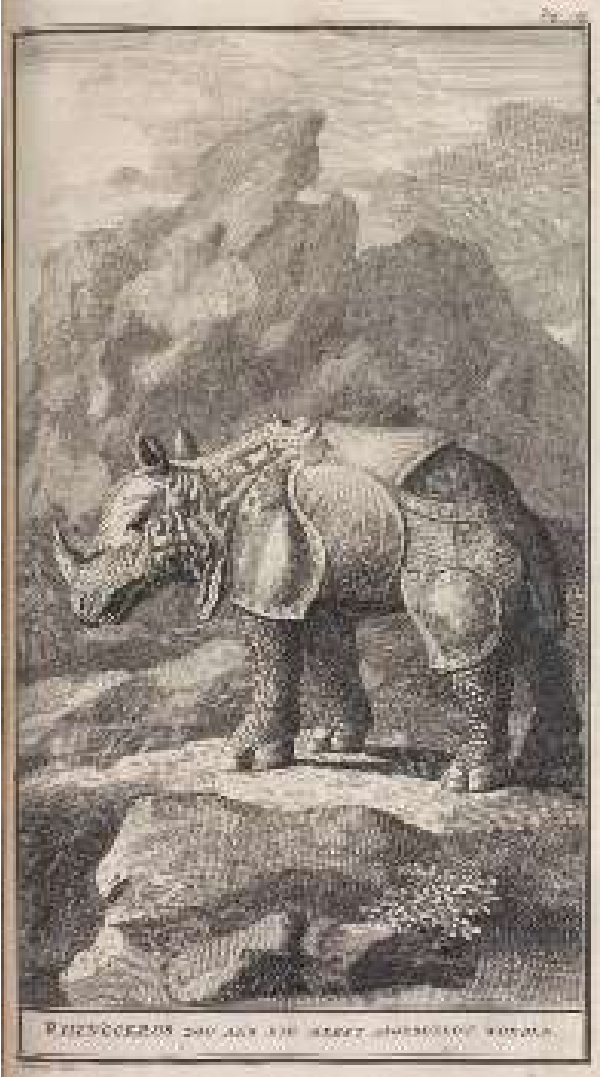

Figure 0 4: Jan Wandelaar, "The Rhinoceros as it had been commonly Depicted", in Kolb (1727, p. 189). Allard Pierson, University of Amsterdam, AB 072:03.

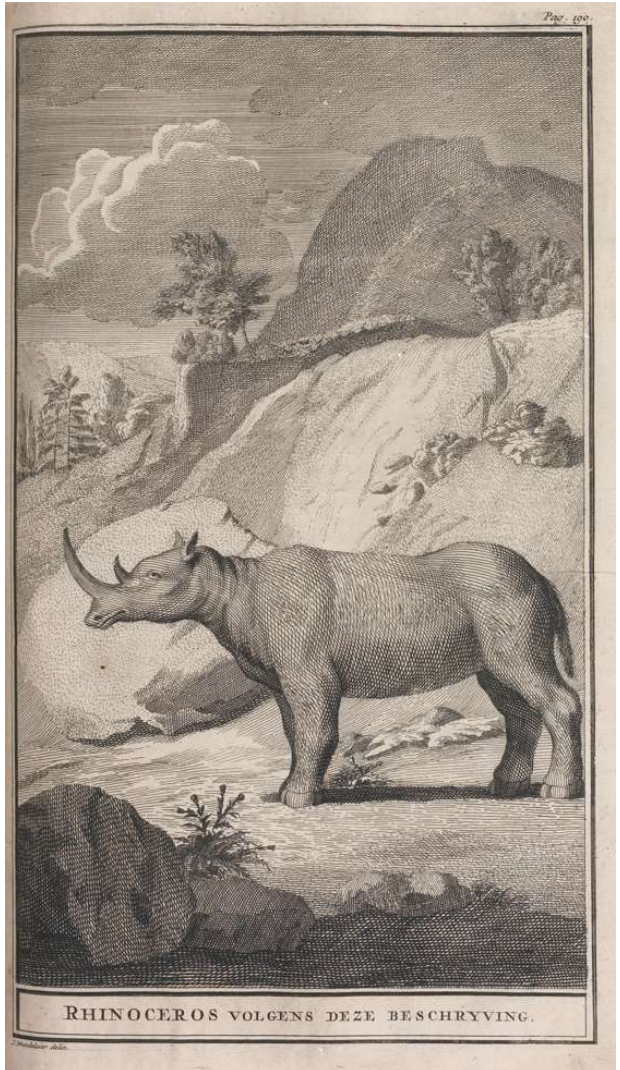

Figure 0 5: Jan Wandelaar, "The Rhinoceros According to this Description", in Kolb (1727, p. 190). Allard Pierson, University of Amsterdam, AB 072:03.

Feyerabend's use of Gombrich in "Problems of Empiricism" remains sketchy and ambiguous, but it seems that Art and Illusion provided him with visual and historical ammunition in support of the claim that the stability and uniformity that "radical empiricists" in his time attributed to the contents of perception was itself at best a conjecture. Indeed, earlier on in the very same footnote to "Problems of Empiricism" he states: "what we receive from the outer world (and from the so-called "inner" world) are certain clues, which most of the times are pretty vague and indefinite. Perception is the result of the reaction of the organism to these clues" (Feyerabend 1965, p. fn. 8 220). Gombrich's account of making and matching provided him with a visual and psychological counterpart for the claim, advanced by his pragmatic theory of observation, that perceptions and sensations become observational reports when they are interpreted in light of theory. Just like images in Gombrich, so observational reports are conjectures about the world, formulated with the aid of conventions and in a particular style. But what Gombrich provided him with was also an initial way to rethink the relationship between sense data, observation, and representation in dynamic terms, a point 
that would be crucial to Feyerabend's later critique of "imitative philosophies" of art and science alike in Conquest of Abundance.

While "Problems of Empiricism" invokes the question of pictorial styles specifically in relation to observation, in the 1980s Feyerabend's interest in art shifted toward a sustained comparison between science and art on historical grounds. Interestingly, in turning explicitly to the question of styles in their historical contexts, Feyerabend drew on a source in art history that had constituted the very foil against which Gombrich shaped his entire approach: the Austrian art historian Alois Riegl. It is to Riegl's influence on Feyerabend that I turn in the next section.

\section{Science as Art}

In later writings, Feyerabend's use of art extends beyond a critique of empiricism, in line with the turn toward pluralism in society that characterised his works in the late '70s and '80s (Brown and Kidd 2016, p. 3). Here art is one of the non-scientific traditions that Feyerabend uses to "defend society" from the authority of science. These are the years in which Feyerabend describes his philosophy as "relativist", insofar as it places science as one tradition among others (ibid). It is to this phase that the essay Science as Art (1984) belongs, its core message being that science is not different from the arts, as the practices and outcomes of both fields are contingent upon the deliberate choice of particular styles. The choice of a style for Feyerabend is a social act in the sciences as much as it is in the arts, and the analogy between the two fields aims precisely at fleshing out how criteria of truth, reality, success and verification are internal to the particular style that communities decide to adopt at a certain time in history.

The beginning of Science as Art will look familiar to readers acquainted with Conquest of Abundance. The essay opens with the description of a painting of legendary fame: Brunelleschi's depiction of the Baptisterium in Florence, celebrated as the first systematic application of perspective to painting. Feyerabend was well aware that perspectival rendering was already a feature of Classical art, but the main point in this section of his essay is to demonstrate how Brunelleschi contributed to elevate perspective to the status of a science, through the application to painting of precise geometric and optical rules. He achieved this through a simple demonstration, which for Feyerabend exhibits all the characteristics of a scientific experiment (Feyerabend 1984, p. 96). First, Brunelleschi produced an image of the Baptisterium as seen from a precise spot by the doors of the nearby Cathedral of Santa Maria del Fiore. Having drilled a little hole in the centre of the painting, he held it about five feet from the ground, standing exactly in the place from which the image was taken. He then held a mirror just across the painting, so that it would produce a reflection of the depiction of the Baptisterium, which could be seen through the hole at the centre of the painting. At this stage of the experiment, Feyerabend notes, Brunelleschi saw a combination of art and reality: the mirror reflected the painting of the Baptisterium in its lower half, and the sky and clouds above Florence in its upper part $($ ibid $)$. He finally removed the mirror, and the image before his eyes remained unchanged - except that it was the "real" Baptisterium that he now saw through the hole in the painting.

As I will show in the next section, Feyerabend will revisit (and partially reinterpret) Brunelleschi's experiment in chapter four of Conquest of Abundance. In Science as Art, the experiment functions as a springboard to think historically about the possible origins of the "naïvely imitative view" of art and how it might have gained 
To appear in Karim Bschir and Jamie Shaw (eds), Interpreting Feyerabend: Critical Essays Cambridge University Press

Please cite from the published version

momentum and credibility precisely through its relationship with the sciences. It is at this point that Feyerabend introduces a landmark study in the history of artistic styles: Alois Riegl's Late Roman Art Industry (Spätrömische Kunstindustrie) ([1901] 1985). ${ }^{14}$ Riegl's work resonated with Feyerabend's argument precisely because it questioned the commonsense view of linear progress toward increasing fidelity to nature, culminating in the naturalistic triumph of perspective. The core message of Late Roman Art Industry was that periods of alleged artistic decadence, traditionally dismissed by art historians, should be studied in their own right and regarded as characterised by their own distinctive and coherent styles. ${ }^{15}$ A member of the Vienna School of Art History, and a proponent of formal analysis as a distinctive art historical methodology, Riegl argued specifically against the then widespread view that late Roman and early Christian art, sculpture, architecture, and crafts were mere residues of Classical art, stripped of its pagan connotations and copied by inexperienced artisans. The historiography of art of the time saw this period of artistic decay as mirroring the decline of the Roman Empire; against this view Riegl argued that the artistic production of the time should be regarded instead as expressing a distinctive and coherent Kunstwollen, variously translated as "artistic volition" or "will-to-art", informing different artistic periods and styles. It was this "will-to-art" internal to each style, and not an increased fidelity to nature, which should be the basis against which styles themselves and their peculiar characteristics should be judged.

Riegl's concept of Kunstwollen is still the object of divergent interpretations among historians of art. Margaret Iversen interprets it as a response to naïve empiricist as well as determinist, functionalist and materialist tendencies in history of art. "Its emphasis on will", she claims, "was meant to retrieve agency in artistic production from the domain of causal explanation" (Iversen 1993, p. 6). Jas' Elsner (2009, p. 748ff), along different lines, interprets it as an expression of Riegl's empiricism, and precisely as a methodological solution to the question of how empirical observations of particular objects in history of art can lead to convincing historical generalisations. Riegl's Kunstwollen "is encapsulated by the struggle between the artist and the limitations imposed by the material he works on and his own technical capacities" (Elsner 2009, p. 750). As such, the concept applies to individual works of art as well as to art in general - showing that special cases and typical examples share a fundamental structure.

Neither of these interpretations was the received view of Riegl's Kunstwollen in Feyerabend's time, however. Instead, what Feyerabend might have had access to was the scathing critique of Riegl put forward by Gombrich in the introduction of Art and Illusion, which is worth quoting directly:

There is a touch of genius in the single-mindedness by which Riegl tries by one unitary principle to account for all stylistic changes in architecture, sculpture, painting, and patternmaking. But this single-mindedness, which he took to be the hallmark of a scientific approach, made him a prey to those prescientific habits of mind by which unitary principles proliferate, the habits of mythmakers. The...Kunstwollen becomes a ghost

\footnotetext{
${ }^{14}$ Drawing (cautiously) on Feyerabend's autobiography, Ginzburg (1998, p. 43ff) suggests that he might have been exposed to Rieglian ideas since at least the 1940s.

${ }^{15}$ Riegl's works and their importance in the historiography and methodology of late Roman art and archaeology have seen a revival since the 1990s. The two works in English that contributed to give new visibility to his works are Olin (1992) and Iversen (1993). Interestingly, Olin spotted the German edition of Feyerabend's Science as Art, which she briefly mentioned in a footnote as an example of philosophers and scientists' recent interest in "Riegl's presumed cultural relativism" (Olin 1992, p. fn. 10 191). For a sophisticated account of the empiricist roots of the concept of Kunstwollen see Olin (1992) and Elsner (2006).
} 
To appear in Karim Bschir and Jamie Shaw (eds), Interpreting Feyerabend: Critical Essays

Cambridge University Press

Please cite from the published version

in the machine, driving the wheels of artistic development according to 'inexorable laws' (Gombrich [1960] 2002, p. 16).

If this critique has a distinctive anti-Hegelian flavour, it is precisely because Gombrich interpreted Riegl in teleological, historicist terms. "By inculcating the habit of talking in terms of collectives, of 'mankind', 'races' or 'ages', it [Riegl's kind of history of art] weakens resistance to totalitarian habits of mind" (Gombrich [1960] 2002, pp. 16-17). And if the charge of falling prey to "prescientific habits of mind" sounds Popperian, it is because Popper was indeed the main drive behind Gombrich's vitriolic critique: only a paragraph later Gombrich invokes The Poverty of Historicism in support of his assessment of Riegl's methodology.

In Science as Art, Feyerabend does not seem particularly worried by the potentially historicist overtones of Riegl's approach (though he would reconsider his use of Riegl later, in Conquest of Abundance). Instead, he interprets Riegl's concept of Kunstwollen as a claim about the internal coherence toward which each style strives, ${ }^{16}$ and from there he derives a series of arguments against linear conceptions of progress to be carried over from art to science. Late Roman architecture, for example, presents a distinctive conception of space: "It recognised space as a cubic material quantity", Feyerabend (1984, p. 116) explains citing directly Riegl, "[and] it differs in that from ancient Near Eastern and classical architecture; but it does not recognise it as an unlimited shapeless quantity - which makes it different from modern architecture" (Riegl [1901] 1985, p. 43). Sculpture obeys similarly consistent stylistic principles: the reliefs of the Arch of Constantine in Rome, Feyerabend notes, referring to one of Riegl's most celebrated examples, are the culmination of the "spatial isolation of the figures" (Feyerabend 1984, p. 117; Riegl [1901] 1985, p. 53) toward which the late Roman style strove. The same can be said of late Roman portraiture, and especially of the rendering of individual figures in late Roman mosaics, where all the parts are reproduced in equal measure, independently of how they are positioned in space.

The first lesson Feyerabend draws from Riegl in Science as Art is that differences in styles are expressions of particular artistic intentions, and as such they defy any characterisation in terms of linear progress or decline. The triumph of perspective, celebrated by Vasari as the culmination of figurative realism, is only one among such expressions. The discussion of the Baptisterium is a case in point. Brunelleschi's experiment, Feyerabend argues, involves the comparison of $t w o$ artefacts, both expressions of the perspectival style characteristic of the Renaissance: the painting of the Baptisterium, and the Baptisterium as it appeared to an observer located in a precise position and

\footnotetext{
${ }^{16}$ Feyerabend's adoption of the term resonates with at least two characterisations of styles widely discussed in philosophy of science. One is Ludwik Fleck's ([1935] 1981) concept of Denkstil or "thought style", the collective set of precepts, acquired by habit, which act as constraints upon scientific observation. As Lorraine Daston (2008) has noticed, this goes further than the common appeal to the theory-ladenness of observation in traditional philosophy of science: "Fleck was concerned with how perception forged stable kinds out of confused sensations" (Daston 2008, p. 100). This characterisation seems to chime with Feyerabend's views about the conjectural nature of perception, which I discussed in the previous section. A second characterization of styles immediately relevant to Feyerabend's discussion in Science as Art is Ian Hacking's work on styles of reasoning (subsequently relabeled "styles of thinking and doing" (Hacking 1982; 1992; 2012). While Feyerabend never developed a taxonomy of styles (which Hacking himself famously adopted from Alastair C. Crombie's 1994 work, Styles of Scientific Thinking in the European Tradition), what he seems to be looking for in the concept of Kunstwollen could be regarded as analogous to the description of styles as "autonomous and self-authenticating", which is distinctive of Hacking's (e.g. 1992, p. 13ff; 2012, p. 605) characterization. And indeed, Hacking himself later acknowledged Feyerabend's influence on his styles project, which he described retrospectively as driven by Feyerabendian "anarcho-rationalism" (Hacking 2012, p. 600). For an illuminating analysis of the parallels between Riegl and Hacking's respective accounts of styles see Kwa (2012).
} 
To appear in Karim Bschir and Jamie Shaw (eds), Interpreting Feyerabend: Critical Essays Cambridge University Press

Please cite from the published version

trained in the particular style afforded by perspective (Feyerabend 1984, p. 119). This initial consideration for Feyerabend has implications and potential for a further application of Riegl's lessons to the case of science. As in the visual arts, so in the sciences styles allow us to go beyond notions of linear progress and decline. But the payoff of Riegl's account is especially visible, Feyerabend notes, when we apply his views to some of the major themes that have concerned philosophers of science for a long time: reality and truth, success, and the verification of scientific theories.

Feyerabend's application of Riegl to science aims to question the naïve representationalist core of contemporary accounts in philosophy of science, showing how both empiricists and realists ultimately converge in postulating one conception of reality and one mode of representation that can satisfy it. But any attempt at defending this very basic variety of monism, Feyerabend argues, fails at taking the debate any further than Riegl. It could be argued, for example, that pure mathematics is the closest scientific equivalent of the role of forms that Riegl places at the core of different styles. Just like forms in Riegl, pure mathematics provides the scientist with a range of representational techniques that afford an "advanced investigation of reality" (p. 121). What the realist would point out here is that scientists can choose among competing representations, but that process of choice ultimately still aims at isolating the single true representation that best captures reality. We can concede, Feyerabend continues, that perhaps defenders of the authority of science would want to apply a more nuanced version of Riegl's account of art to the case of the sciences. In this nuanced view, we could capitalise on the multiplicity of representational styles in science to suggest that the aim is to compare them, just like we can compare the features of Renaissance and late Roman styles and arrive at a judgment over where one succeeds and others fail. By this account, for instance, late Roman art fails in its representation of space, which is far more successfully and accurately captured with the introduction of perspective. But this more nuanced suggestion, Feyerabend argues, still implies the existence of a neutral point of view from which both styles can be objectively compared, which is precisely what Riegl's notion of Kunstwollen, as interpreted by Feyerabend (pp. 122-123), ${ }^{17}$ calls into question. Appealing to an external notion of reality as an objective criterion will not do either, as it assumes that artists (or scientists) already possess a predefined notion of reality, toward which they orient their practices.

The same line of argumentation applies to philosophers of science's characterisation of the conditions of verifiability of scientific predictions. Affirming that observations can lend more or less support to - or conclusively falsify - a prediction, is itself an assumption built on the idea that there is a single, stable perceptual world against which our theories can be tested. Drawing on the transition from Aristotelian to Galilean physics, Feyerabend shows that even such a simple assumption is an oversimplification: conditions of verifiability are themselves subject to styles. Thus, for instance, Aristotelian observations aimed to ascertain qualities where Galilean physics takes a quantitative approach; in the former predictions have a modest role whereas the latter is almost entirely built upon them, and so

\footnotetext{
${ }^{17}$ Jas' Elsner presents an alternative view on this rather problematic aspect of Riegl's Kunstwollen. On one level, he shows that Riegl did subscribe to a notion of progress - albeit one that is incommensurable with contemporary criteria. Contrasting the late Roman Kunstwollen with that of the Flavians and Trajan, Riegl states that the former "constitutes progress and nothing other than progress. Judged by the limited criteria of modern criticism, it appears to be a decay that did not exist, but modern art with all its advantages would never have been possible if late Roman art... had not led the way" (Riegl [1901] 1985, p. 11). In the same vein, Elsner shows that Riegl himself attempted to compare the modern Kunstwollen of the nineteenth century with the late Roman one, thus at least implying that comparison was possible. See Elsner (2009, p. 751).
} 
on. The upshot of Feyerabend's discussion is that no matter how we try to use reality - in this narrow formulation as the objective grounding for a discussion of styles in art and science, we fall back into Riegl's position, which he explicitly labels as "relativism" (p. 127): styles can only be chosen, developed and evaluated according to criteria internal to themselves.

The upshot of Feyerabend's application of Riegl to science is that reality, truth, success, verification are all ultimately historically contingent choices of particular modes of operating carried out by human beings in precise social contexts. While this was only acknowledged in the case of the arts, the inescapability of Riegl's conception of style when applied to scientific practice is a legitimate ground, Feyerabend argues, to reconsider the sciences as arts in this modern sense (p. 156).

\section{Imitating an Abundant World}

It is to Riegl that the late Feyerabend returns, revisiting his account of style in a critical spirit. Where Science as Art emphasises the inescapable nature of Riegl's relativism, Conquest of Abundance reconfigures Riegl's contribution, highlighting some crucial questions that his account leaves open. "Riegl's observations are a valuable corrective to crude progressivism", Feyerabend here states, but "his positive ideas are another matter" (Feyerabend 1999, p. 93) . Here Feyerabend returns to the question of imitation, which Riegl would consider as dependent on what artists assume reality to be in different historical contexts. While this seems to reconcile imitation and stylistic pluralism, Feyerabend notes that it does so "on the basis of an arbitrary and badly founded assumption" (ibid): the close correlation between artists' assumptions about reality and the practices we identify as "imitation" is merely postulated by Riegl. In this respect, his ideas fare no better than the naïve realist's assumptions about the postulation of the "worldview-independence... of reality" (ibid).

Feyerabend scholars have pointed out that Conquest of Abundance exemplifies the quest for a metaphysical counterpart to radical pluralism (Kidd 2010, Chapter 8; Tambolo 2014) and the broader return to realism which are distinctive of the late Feyerabend (Kidd, 2010; Brown and Kidd 2016; Brown 2016) . In this last section I want to argue that this shift is also at the basis of his return to a richer notion of representation, and to his renewed interest in a notion of imitation as a process. Where Science as Art drew on (Feyerabend's own interpretation of) Riegl's notion of self-consistent styles to advocate the necessity and coexistence of a plurality of representations (with scientific theories, models, explanations and predictions obeying their own internally coherent stylistic criteria), in Conquest of Abundance the metaphysical premise of Feyerabend's account of representation changes. This metaphysical premise is sketched in the opening of the book, now a much-quoted passage by Feyerabend:

The world we inhabit is abundant beyond our wildest imagination. There are trees, dreams, sunrises; there are thunderstorms, shadows, rivers; there are wars, flea bites, love affairs; there are the lives of people, Gods, entire galaxies (Feyerabend 1999, p. 3). 
We can handle only a fraction of this abundance, Feyerabend states, and this is to a certain extent a blessing: "a superconscious organism would be paralysed" (pp. 3-4). But this also means that to make any sense of the world abundance needs to be simplified, either in thought via abstraction or by actively interfering with it via experiments. In both cases a large part of that abundance is "blocked off", and what remains is considered amenable to investigation - and is referred to as "the real" (p. 5).

The metaphysical thesis of an abundant world has been investigated by Feyerabend scholars from various angles. Kidd (2010, Chapter 9; 2012) has connected it to the late Feyerabend's characterisation of the ineffability of reality (Feyerabend 1999, pp. 195-6), and related it to the writings of the Neoplatonist Pseudo-Dionysius the Aeropagite. In analogy with Pseudo-Dionysius' characterization of God's names, explicitly acknowledged by Feyerabend (195), reality as such is ineffable, but "depending on our approaches it may respond in a variety of comprehensible ways" (196). Tambolo (2014) sees abundance as part of Feyerabend's articulation of a broader argument about the limited pliability of reality, a thesis entailing two claims: reality, as Feyerabend states, is pliable (p. 145) - it can be moulded by our descriptions in an indefinite number of ways, each of which answers particular questions we are asking nature. But this pliability is limited by resistance: "some constructions", Feyerabend explains, "find no point of attack... and simply collapse" (ibid). Matt Brown (2016) has brought these accounts together in a systematic reconstruction of Feyerabend's metaphysics, showing that "the abundant world" is a complex but coherent thesis articulated throughout Conquest of Abundance. Brown characterises it as a form of ontological pluralism aimed at refuting "scientific materialism", a family of realist accounts that subscribe to or combine in various ways mindindependence, taxonomical monism (the world has a single, coherent and uniform structure of entities and processes), ontological reductionism (higher order structures can be reduced to the properties and relations of lower order ones), and physicalism (in the formulation that the basic structure of the world is physical). (Brown 2016, p. 143)

All these accounts agree in characterising Feyerabend as denying that there is a single, unique scientific description or representation that will exhaust the "richness of Being" (which Feyerabend uses as synonymous with reality). Kidd (2012) and Brown (2016) also show that Feyerabend's late metaphysics aims at eliminating the artificial (Neo-Kantian) distinction between appearances and reality: the distinction is only a product of the process of simplifying abundance, and it is itself an "invention" of Western philosophy. Instead, Feyerabend differentiates between Being, which he characterises as ineffable, resisting but pliable (as in Tambolo 2014), and "manifest worlds", which are the products of how Being responds to our beliefs, goals, interests and practices (Feyerabend 1999, p. 204). As Brown (2016, p. 147) explains, manifest worlds are neither ideal entities nor phenomenal worlds, they are just evidence of our interactions with Being (or with an abundant reality). "Inhabitants of a particular manifest world", Feyerabend explains, "often identify it with Being. They thereby turn local problems into cosmic disasters" (Feyerabend 2016, p. 204). Conflating the evidence we have of our interactions with the richness of Being with Being itself, amounts to regarding these fragmentary worlds as complete representations of an objective, mind-independent reality (Kidd 2012, p. 369). On the contrary, Feyerabend argues, "the manifest worlds themselves demonstrate their fragmentary character; they harbour events which should not be there, and which are classified away with some embarrassment (example: the separation of the arts and the sciences)" (Feyerabend 1999, p. 204, emphasis added). 
Feyerabend's cursory comment is telling: the separation of the sciences and the arts is yet another result of the fragmentary character of a particular manifest world in which they are regarded as separate domains. To a certain extent, his own work on the relationship between these two fields is thus itself an attempt at recovering a mode of engagement with Being that had been suppressed in the process of simplifying abundance.

It is this metaphysics of abundance which underpins, I claim, Feyerabend's revised account of the role of imitation in representation. Reality, or Being, is abundant. It is an open domain of possibilities which are not exhausted by our descriptions or representations. At the same time, descriptions and representations are among the practices and processes we carry out to come into contact with Being, and as such they are part of particular manifest worlds that evidence our interactions with Being. They are inevitably fragmentary, partial and perspectival - a point that Feyerabend develops in detail in chapter 4 of Conquest of Abundance.

Immediately after revisiting his position on Riegl, Feyerabend moves on to reconsider Brunelleschi's visual experiment with the Baptisterium. Just like in Science as Art, he stresses that Brunelleschi's experiment shares many of the features of scientific experiments: the perspectival construction of the painting obeys rigorous rules derived from architectural practice; the rendering of the Baptisterium is performed under very specific conditions. Again, in line with Science as Art, Feyerabend states that here Brunelleschi is comparing two objects: the painting of the Baptisterium and "something else. This 'something else' was not a building, it was an aspect of a building... Brunelleschi chose an aspect that suited his purpose" (Feyerabend 1999, p. 100). But at this point, Feyerabend introduces a theoretical angle which was not present in his earlier account of the experiment, and which is directly related to the renewed interest in imitation as a process that emerges in Conquest of Abundance. In a sense, Feyerabend argues, Brunelleschi's is an attempt at representing by imitating reality. But to understand how it is necessary to switch from a narrowly visual to a broader, theatrical sense of imitation:

If we want to say that Brunelleschi imitated reality then we have to add that this reality was manufactured, not given... The best way to describe the situation is by saying that Brunelleschi built an enormous stage, containing a pre-existing structure (the Baptisterium), a man-made object (the painting), and special arrangements for viewing or projecting both. The reality he tried to represent was produced by the stage set, the process of representation was part of the stage action, it did not reach beyond it (pp. 100-1).

In his reconstruction of Feyerabend's account of Brunelleschi's experiment, Matt Brown (2006) compares Feyerabend's staging metaphor to the kind of scientific perspectivalism advocated by Ronald Giere (2006). Just like in Giere's view, Brown argues, "man-made objects (paintings, theories) are compared with the World only through projections...Theoretical principles must be transformed into representational models, and the scientist must generate models of data in order to make a comparison" (Brown 2006, p. 217; cf. also Giere 2006, Chapter 4). But Brown takes the Feyerabendian account of representation one step further, showing that the staging metaphor entails also the creation of an audience, "the mostly unspecified agent in Giere's account" (Brown 2006, p. 217). In Feyerabend's reconstruction, Brown shows, theories are not compared with the world. Instead, what is compared is two functional artefacts: representational models and models of data. Moreover, Brown continues, "the similarity or fit between these 
two objects, is not an abstract relation, but it is an act carried out by agents fulfilling another functional role in the process of representation, the audience" (ibid).

As in every theatrical metaphor (as well as in actual theatrical performances), "audience" here can be constructed in two ways. One is passive: the staged performance "directs" the audience's attention in particular ways. But this is clearly not the sense intended by Brown, who states that scientists qua audiences have a functional role in the process of representation. The other is active: the staged perspective, as in a play, dynamically moves the audience toward new possibilities (the audience can make choices and take decisions on how to interpret and act upon the staged representation). It is this second, active sense of "audience" that Brown seems to be hinting at, and it is this dynamic sense of "staging" as involving audiences and their agency, I claim, that can be used to make sense of the Feyerabendian way of reconsidering the role of imitation as a process in Conquest of Abundance.

The dynamic sense of imitation I want to attribute to the late Feyerabend is one of Aristotelian legacy, and it is precisely the notion of mimesis that Aristotle saw at work in drama. ${ }^{18}$ Indeed, the Aristotelian version of the imitative view is cursorily acknowledged by Feyerabend in chapter 4 of Conquest of Abundance: "The imitative view... was developed by Aristotle (tragedy imitates deep-seated social structures and is therefore "more philosophical" than the most painstaking historical account)" (Feyerabend 1999, p. 92; cf. also 1987, p. 129). In Farewell to Reason, Feyerabend proves to be well acquainted with the subtleties that characterised the concept of mimesis in antiquity and through the centuries. In the space of two pages, he presents the trajectory of mimesis from Book 10 of Plato'sRepublic, where artists are criticised "for imitating the wrong entities,... for making deception... part of their imitative techniques, and for arousing emotions" (p. 128), to Aristotle's revival of the concept in his theory of drama "contained in his magnificent Poetic" (ibid), to the revival of mimesis in the Renaissance and all the way to the invention of photography in the mid-nineteenth century (p. 129). What this history shows, Feyerabend claims, is that "imitation is a complex process that involves theoretical and practical knowledge (of materials and traditions), can be modified by invention, and always involves a series of choices on part of the imitator" (p. 130). The staging metaphor in chapter 4 of Conquest of Abundance capitalises on the subtle differences that characterised the history of mimesis, and of which Feyerabend was clearly aware. Imitation is one of the many practices included in our manifest worlds, one of the ways in which we come into contact with a pliable and abundant reality. As such, there is not a single, correct way of imitating reality. There is no single, unified concept of mimesis. And there is no linear progress toward increasingly more faithful representations, because the criteria according to which we imitate are contingent upon our interactions with reality and our interpretations of how reality responds to our interests, beliefs and practices.

In his monumental The Aesthetics of Mimesis (2002), Stephen Halliwell proposes that the history of this philosophically contested concept is characterised by the tension between two conceptions: on one hand, there is a view of mimesis as "outward-looking", or committed to illuminating a world that is (partly) accessible outside art, and by whose norms art can be tested and judged. On the other, there is a notion of mimesis as "inward-looking/world simulating/world creating". In this second account of Aristotelian legacy, mimesis is construed as the creator of an

\footnotetext{
${ }^{18}$ See in particular Poetics, Book 9.
} 
independent "artistic heterocosm" - a world of its own, but also one which still contains some truth about reality as a whole (Halliwell 2002, p. 5). The philosophical history of mimesis, Halliwell claims, is ultimately the history of the perpetual tension between these two views. More importantly, Halliwell shows through painstakingly detailed work on historical texts that the history of mimesis shows "no central commitment...to the truth-bearing, as opposed to the sense-making, status of mimetic works" (p. 380). This is a claim that Feyerabend would have been sympathetic to and to a certain extent it is in this direction that his own overview of imitation "as a complex process" heads. But even more, Feyerabend would have been sympathetic to Halliwell's reconstruction of Aristotelian mimesis, which, I claim, lurks in the background of his metaphor of representing as "staging", and is compatible with the metaphysical outlook he adopts in Conquest of Abundance more broadly.

In the Poetics, Aristotle characterises poetry distinctively as a mimetic art concerned with "things which could be the case, and which are possible in terms of probability or necessity" (Poetics 9.1451a37-38, emphasis added). ${ }^{19}$ It is this character of possibility that opens up an account of mimesis to an interpretation that Feyerabend would find congenial. Mimesis in Aristotle is bound and related to intentionality (of the makers, performers and audiences of a representation), and as such it cannot be exhausted by sensory correspondence. "Mimetic likeness" Halliwell states, "entails an intentionality that is ultimately natural in origin but becomes embodied in culturally evolved and institutionalised forms. This is one reason why not all likenesses are mimetic: not all likeness has the intentional grounding that is a necessary condition of artistic mimesis" Halliwell (2002, p. 156). This account of mimesis, Halliwell continues, is relational and transformative: "Constituted partly by the experience that it opens up for, and introduces in its audience" (p. 161). This Aristotelian notion of mimesis brings together creatively makers, performers and audiences of a representation, and is connected by Halliwell to broader perspectival accounts in epistemology. Drawing a parallel with Putnam's (1992) Realism with a Human Face, Halliwell argues that this Aristotelian account of mimesis is "a locus of possibilities within a fully human perspective, a perspective that interprets 'reality' through culturally structured but disputable (and amendable) frameworks of beliefs, standards and conventions rather than by a set of metaphysically absolute reference points" (Halliwell 2002, p. 376, emphasis added).

Translated in Feyerabend's terms, this would amount to say that likeness or imitation is not a single, unified category that cuts across all manifest worlds. And indeed, this is one of the core messages of his investigation of Brunelleschi's experiment, which incidentally also took Feyerabend all the way back to the issue of styles: "interpreting artworks as stage sets" he claims in chapter 4 of Conquest of Abundance, "provides a precise and useful framework for discussing a variety of assumptions about the scope, function, and development of artistic styles" (Feyerabend 1999, p. 101). First, the stage metaphor gives the makers of representation a new sense of agency. With a nod to Gombrich's criticism of Riegl, Feyerabend points out that artists have substantive control over changes in styles: "Brunelleschi was not swept along by overwhelming historical forces; he prepared every step of his

\footnotetext{
${ }^{19}$ Here I am using Halliwell's own translation of Aristotle's passage, in Halliwell (2002, p. 154). In an earlier translation, (Aristotle and Halliwell, 1987, p. 40) Halliwell presents the passage as follows: "the kind of events which could occur, and are possible by the standards of probability or necessity" (emphasis in the original).
} 
performance" (ibid). In distancing himself from the historicist readings of Riegl, Feyerabend here suggests between the lines that it was the local account of agency built into the concept of Kunstwollen (rather than its historicist overtones) that attracted his attention in the 1980s. For the late Feyerabend this is best exemplified in the notion of manifest worlds: rather than driven by an unspecified "will-to-art", representative styles are themselves the result of our interactions with a pliable reality. Secondly, this time against a purely conventionalist reading of Gombrich, the staging metaphor dispels the idea "that it is mind and mind alone that imposes a style and that styles are therefore conventions, free from the impediments of the material world" (ibid). The materiality of Brunelleschi's experiment mattered: the correct application and use of his experimental apparatus allowed a particular perspectival representation - an aspect of the Baptisterium - to emerge as a result of the interplay between pliability and resistance distinctive of the manifest world in which Brunelleschi operated. But it is also the case, Feyerabend continues, that the representation did not obey exclusively physical laws. True, the final picture of the Baptisterium was constructed with the aid of rules that are based, for instance, on approximations of the laws of propagation of light. But these laws alone do not guarantee that a human, correctly positioned, "will see things accordingly" (p. 102). Just like in Halliwell's account of mimesis, manifest worlds give us perspectival representations "within a fully human perspective": they express particular configurations of our interactions with a pliable but resistant reality, according to conventions that render those perspectives amendable and amenable to public scrutiny.

This takes us full circle to where we started: to the "ugly Madonna of Siena", who "might have caught an element of reality", but as Feyerabend argues, "this must be established by research, not by metaphysical speculations about "the nature of reality" (pp. 93-94). And "research" is precisely what compels us to inscribe representations within the stages - the manifest worlds - in which they are produced, performed and negotiated. As a "locus of possibilities", imitation is a varied and creative process, which captures the ways in which we interact with reality and reconstitute it on the basis of our interpretations of reality's responses. This is precisely the conclusion to which Feyerabend arrives through his long journey from scientific to artistic representation, and back again:

Being in the world we not only imitate and constitute events, we also reconstitute them while imitating them, and thus change what are supposed to be stable objects of our attention (p. 128, emphasis added).

\section{Conclusions}

In this chapter I explored Feyerabend's writings on art and placed them in dialogue with some of the milestones in his philosophy of science. I focused on his treatment of representation across art and science, tracing the journey that took him from "Problems of Empiricism" to Conquest of Abundance. I showed how his critique of "naïvely imitative philosophies" of the empiricist and realist variety compelled him to draw on sources in the history of art to formulate a sophisticated, dynamic account of imitation in art as well as science.

I highlighted two interconnected lines of inquiry in Feyerabend's approach to representation. One is the pervasiveness of the issue of artistic styles, which Feyerabend exploited as a springboard to question "naïvely imitative" views in science. Two influential sources in these early and middle phases of his philosophy were Ernst 
To appear in Karim Bschir and Jamie Shaw (eds), Interpreting Feyerabend: Critical Essays Cambridge University Press

Please cite from the published version

Gombrich and Alois Riegl. Gombrich's account of making and matching provided Feyerabend with an empirical and theoretical grounding in the methodology of art history, which also offered him a compelling analogy to rethink the relationship between sense data, observation, and representation in dynamic terms. Riegl's concept of Kunstwollen helped him shift from the individual psychology of perception distinctive of Gombrich's account to a collective, historicised (albeit not "historicist", in a Hegelian sense) notion of style. I showed that while the early Feyerabend suspended his judgment about the potentially historicist overtones of Riegl's account, the later Feyerabend showed at least some awareness of the implications of Gombrich's criticism of Riegl's historicism. But by that point, what Feyerabend was initially looking for in the concept of Kunstwollen had been replaced by the more nuanced notion of “manifest worlds", as expressions and evidence of scientists' (and artists') interactions with a pliable reality.

The second line of inquiry I identified in Feyerabend's journey from science to art is the question of imitation as a conceptual category in its own right and its relation to representation. Here Feyerabend's ideas aligned once again with the various phases of his philosophy. Science as Art drew on the analogy between styles in art and science to expose the flaws of linear notions of scientific progress, implicit both in realist and verificationist accounts of science. In this context, "naïvely imitative philosophies" formed the core of Feyerabend's attack against a narrow conception of progress construed as increasing fidelity to nature and were in line with his views about the necessity of pluralism in society, and his defence of society from the authority of science. Conquest of Abundance, on the other hand, rescued a role for imitation as one possible mode of representation. But it did so based on the different metaphysical premise of an "abundant world". The late Feyerabend found a new space for imitation (though he never reduced representing to imitating) as a dynamic, performative category, and as a mode of reconfiguring a pliable reality while imitating it.

There is much more to Feyerabend's views on art than the account of his changing views on imitation I outlined in this chapter. While his passion especially for Renaissance painting is at least partly known, his writings on theatre, especially on Bertolt Brecht and Eugène Ionesco, have only been very partially explored (cf. Couvalis 1987). The now established scholarship on Brecht's critical reception of Aristotle's Poetics (see for example Halliwell 1998, p. 316ff; Curran 2001; Halliwell 2002, pp. 372-374), for instance, could serve as an interpretative framework to reread the metaphor of staging in Conquest of Abundance and place it in dialogue with Feyerabend's broader and continued interest in the aesthetics of performance. Along complementary lines, Feyerabend's rich writings on art and science are beginning to serve as a conceptual framework for artistic research, especially when engaged in a critical dialogue with science (see for example Magee 2018). Here I tried to open an avenue of inquiry which could be taken in a multitude of novel directions, especially by scholars who, in a Feyerabendian spirit, will disagree with the interpretation I presented of his account of representation. There is much more to Feyerabend's writings on art: just like his characterisation of reality, they are "abundant beyond our wildest imagination".

\footnotetext{
Acknowledgments: This chapter owes a great deal to the community of Feyerabend scholars who encouraged me to firm down in writing my thoughts on Feyerabend on art and science. I am especially grateful to Jamie Shaw and Karim Bschir for inviting me to contribute to this volume, and for their constructive comments on earlier drafts of this chapter. Almost twenty years ago now, Hasok Chang taught me Feyerabend in the most inspiring and most effective way: by asking me to teach him. I have been a practicing Feyerabendian ever since, and never stopped being grateful for it. Ian Kidd kept insisting that I write about Feyerabend on art and science, and proactively made it happen by inviting me as a keynote speaker to the wonderful conference "Feyerabend
} 
To appear in Karim Bschir and Jamie Shaw (eds), Interpreting Feyerabend: Critical Essays

Cambridge University Press

Please cite from the published version

2015: Forty Years 'Against Method'”, held at Durham University. The participants of the Egenis Research Exchange reading group at the University of Exeter provided invaluable comments to this chapter. I am especially grateful to Gemma Anderson, Benjamin Smart and Sabina Leonelli, for organising the reading group and pre-circulating a draft of this chapter amongst its participants. Niall Le Mage read and commented every iteration of this chapter, and provided precious technical support with the images. More importantly, he caught me out every time I did not practice the pluralism I preached, proving to be the real Feyerabendian in our home! Last but not least, this chapter is dedicated to my three students and fellow anarchists Adam Holland, Rachel Fong, and Paul Magee, whose insightful works and enthusiasm in Feyerabend's ideas made me a better scholar and a better person. 
To appear in Karim Bschir and Jamie Shaw (eds), Interpreting Feyerabend: Critical Essays Cambridge University Press Please cite from the published version 